\title{
Educação Física escolar: formação ou pseudoformação?
}

\section{Marcus Aurelio Taborda de Oliveira*}

"Não o fiz porque não me agrada ceder à pusilanimidade; começa-se por ceder nas palavras e se acaba cedendo nas coisas. (...) quem sabe esperar não tem necessidade de fazer concessões".

Sigmund Freud em Psicologia das massas e análise do Eu.

\section{RESUMO}

Neste trabalho procuro discutir a permanência das práticas competitivas no interior das aulas de Educação Física na escola básica. Partindo do referencial da Teoria Crítica, proponho uma reflexão sobre os limites formativos das práticas corporais de caráter competitivo. Antes de afirmar uma possibilidade de formação emancipatória essas práticas concorrerem para perpetuar a reificação dos indivíduos e de suas relações com a sociedade e com os demais indivíduos, uma vez que as práticas competitivas são, por definição, seletivas e, portanto, excludentes. Reivindicando para a Educação Física escolar um papel preponderante na formação humana, recorro aos trabalhos de Herbert Marcuse, Max Horkheimer e Theodor Adorno para reafirmar o potencial de resistência e crítica à cultura reificada impresso nas práticas corporais escolares.

Palavras-chave: Educação Física escolar, corporalidade e formação humana, Educação Física escolar e competição.

\footnotetext{
ABSTRACT

This work aims at discussing practices in Physical Education classes. From a Critical Theory, a reflection about the limits of these practices in

* Doutorando em Educação: História, Política, Sociedade pela PUC/SP. Professor do Departamento de Teoria e Prática de Ensino da Universidade Federal do Paraná. marcusat@educa-
} cao.ufpr.br 
school is proposed. Before a possibility of education emancipation, these practices contribute to the maintenance in society. There are people self-converted into objects. From Herbert Marcuse, Max Horkheimer and Theodore Adorno's works, resistance and critical potential of corporal practices in school are searched for.

Key-words: Physical Education in the school, corporal practices and human formation, Physical Education and competition.

Muito se tem discutido e já há muitos anos, sobre a pertinência da Educação Física no interior da instituição escolar. Sob os sinônimos de sentido, significado, relevância ou legitimidade, essa discussão tem atravessado os anos sem alterar de forma significativa o quadro atual da Educação Física no interior da escola. Alguns pesquisadores apontam o abismo existente entre a academia e realidade escolar como uma causa provável do imobilismo dessa prática escolar. Outros defendem que a formação inicial tem se mostrado extremamente deficiente quando se trata de atender às demandas do cotidiano. Outros ainda, insistem na velha tese das péssimas condições de trabalho dos professores, o que os tornaria refratários a qualquer perspectiva de mudanças. Por fim, existem aqueles que destacam a necessidade de os professores serem co-partícipes de quaisquer reformas/mudanças que se pretendam exitosas. Eu não descartaria qualquer uma das possibilidades anteriores. Porém, também não reduziria a discussão a termos tão localizados. No meu entendimento, um fator tem contribuído para a permanência da Educação Física numa condição secundária como prática educativa escolar: para que a Educação Física forma o indivíduo, se é que o forma? E especulando tenderia a afirmar que poucos profissionais - pesquisadores ou professores escolares - teriam uma resposta para essa questão, que fugisse dos jargões da formação para a educação integral, para a saúde, para a qualidade de vida, para o gosto pela atividade física permanente, para a sociabilização, para a utilização do tempo livre e por aí afora. Sem entrar no mérito do substrato ideológico de muitas das asserções acima, gostaria de propor uma reflexão em torno da prevalência de um princípio básico que norteia as aulas de Educação Física ainda hoje: o princípio da competição. Esse princípio tem orientado uma prática escolar calcada na força, na superação constante de limites e obstáculos, na eliminação do outro, enfim, nas várias formas manifestas de dominação. E tem sido justificativa de manutenção de procedimentos incapazes de levar a cabo a formação humana em sua plenitude.

Por muito tempo se convencionou relacionar a competição com o esporte, relação lógica na medida que o esporte se funda basicamente no en- 
frentamento, seja com outros indivíduos ou equipes, seja com obstáculos naturais, seja com os próprios limites do indivíduo. Ocorre que, com a recuperação pela Educação Física de outros saberes até então secundarizados - a dança, a ginástica, a acrobacia, a dramatização -, demonstrou-se que a ênfase na competição não tem sido prerrogativa das práticas esportivas. Mais e mais é possível observar práticas de dança, por exemplo, transformadas em torneios e gincanas. Assim como se mantém a idéia de que tudo aquilo que o aluno desenvolve na aula deve ser condecorado, mesmo que seja uma dramatização corporal da qual o aluno não espera auferir qualquer tipo de vantagem. Sem contar os malfadados "jogos escolares" francamente classificatórios, eliminatórios, seletivos; portanto, discriminatórios. Enfim, o princípio competitivo tem se espraiado pelas aulas de Educação Física, independente do tipo de saber que a escola tem oferecido aos alunos, seja o esporte ou não. Ao invés de retomar a discussão para a qual a Educação Física cumpriria uma função meramente ideológica, portanto de manutenção do status quo, tendo como referencial algumas reflexões de Theodor Adorno, Max Horkheimer e Herbert Marcuse, pretendo discutir as possibilidades atuais da Educação Física como prática formativa escolar.

Já no Excurso I da Dialética do esclarecimento (1985), Adorno e Horkheimer demonstram como, a partir da saga do mito Ulisses, a formação humana foi calcada no embrutecimento do indivíduo e não no desenvolvimento da sua sensibilidade. A necessidade de superação da natureza - diante de condições objetivas - converteria o astuto Ulisses no protótipo do indivíduo burguês. Sua astúcia radicaria tanto as possibilidades de autoconservação quanto as possibilidades de instalação e perpetuação da dominação, assim como da perpetuação do eu idêntico. "O recurso do eu para sair vencedor das aventuras: perder-se para se conservar, é a astúcia. O navegador Ulisses logra as divindades da natureza, como depois o viajante civilizado logrará os selvagens oferecendo-lhes contas de vidro coloridas em troca de marfim". (p. 57). Ora, o sacrifício e a dominação expressos naquele recurso não ficariam sem correlatos:

Enquanto os indivíduos forem sacrificados, enquanto o sacrifício implicar a oposição entre a coletividade e o indivíduo, a impostura será uma componente objetiva do sacrifício. Se a fé na substituição pela vítima sacrificada significa a reminiscência de algo que não é um aspecto originário do eu, mas proveniente da história da dominação, ele se converte para o eu plenamente desenvolvido numa inverdade: o eu é exatamente o indivíduo humano ao qual se credita mais a força mágica da substituição. A constituição do eu corta exatamente aquela conexão flutuante com a natureza que o sacrifício do eu pretende estabelecer. 
Todo sacrifício é uma restauração desmentida pela realidade histórica na qual ela é empreendida. (ADORNO; HORKHEIMER, 1985, p. 58-59)

A idéia do sacrifício como constituinte do próprio indivíduo é representativa não só do estranhamento e do medo, como da própria separação do homem da natureza. Separação que redundaria na dominação da natureza pelo homem, bem como na dominação do próprio homem.

\begin{abstract}
Com a negação da natureza no homem, não apenas o telos da dominação externa da natureza, mas também o telos da própria vida se torna confuso e opaco. No instante em que o homem elide a consciência de si mesmo como natureza, todos os fins para os quais ele se mantém vivo - o progresso social, o aumento de suas forças materiais e espirituais, até mesmo a própria consciência - tornam-se nulos, e a entronização do meio no fim, que assume no capitalismo tardio o caráter de um manifesto desvario, já é perceptível na proto-história da subjetividade. O domínio do homem sobre si mesmo, em que se funda o seu ser, é sempre a destruição virtual do sujeito a serviço do qual ele ocorre; pois a substância dominada, oprimida e dissolvida pela autoconservação, nada mais é senão o ser vivo, cujas funções configuram, elas tão somente, as atividades da autoconservação, por conseguinte exatamente aquilo que na verdade devia ser conservado. (ADORNO; HORKHEIMER, p. 60-61)
\end{abstract}

Esse processo de afirmação do homem burguês aponta claramente para a substituição das funções prazerosas pela necessidade de autoconservação. É eminentemente um processo de dominação. $\mathrm{O}$ indivíduo então se afirma através do seu endurecimento e da sua frieza. Ou seja, afirma-se como sujeito amoral, uma vez que o único valor para ele é a sobrevivência.

Essas reflexões iniciais são necessárias na medida que muito se advoga que a competição é um elemento "natural", constitutivo do próprio homem. Ora, o processo de constituição do indivíduo representa, como estamos vendo, a separação do homem da natureza. A justificativa da competição como um $a$ priori natural estaria no seu sentido diametralmente oposto, uma vez que superando a natureza o homem teria superado o seu impulso competitivo de quando ainda se confundia com ela, ou seja, de quando ainda necessitava dominá-la para autoconservar-se. Mas sabemos que não foi assim: a dominação da natureza é um dos elementos mais caros às práticas competitivas: superação de marcas, de obstáculos, de limites, de adversários são a sua face mais aparente. Nos restaria então algumas hipóteses: a competição seria um elemento de regressão a um prazer primitivo. Ou se apresentaria como uma dimensão humana, dissimulando uma sociedade ancorada na premissa do darwinismo social; nesse caso, o seu discurso tem o fito claro de dissimular a sua dimensão ideológica. E como última hipótese, a competição estaria imbricada 
no mesmo processo que constituiu o indivíduo; ou seja, ela estaria pautada por uma lógica de dominação da natureza - e do outro como seu corolário -, no sacrifício, na astúcia, na atomização dos indivíduos tornados mônadas e na reificação das relações entre os indivíduos e entre esses e a natureza. Partilho dessa hipótese, que no meu entendimento engloba as demais, a dominação do outro, ou pelo menos a sua superação, implica claramente um afastamento para poder dominar, ou seja, num estranhamento. Esse estranhamento pelo sujeito diferente oferece a oportunidade para que o reconheçamos como diferente, mas também, para que nos lancemos contra ele como algo estranho. $\mathrm{O}$ outro que divide conosco o momento competitivo se nos apresenta como algo a ser superado, vencido, abatido, dominado, subsumido à escala hierárquica onde despontamos como os grandes vencedores. Isso está implícito tanto nos jogos esportivos quanto na prática escolar da avaliação baseada na meritocracia. Quem não se depara com uma tipologia corrente que segrega os alunos em bons e maus, ótimos e péssimos, espertos e apáticos? As diferenças singulares são reduzidas a escalas classificatórias e valorativas: o bom aluno joga bem; o mau aluno não sabe jogar; o aluno apático corre pouco, o aluno veloz é esperto. Em que medida esses indivíduos que são nossos alunos aprovam essa forma de desenvolver um trabalho com as práticas corporais? Um dos motivos do propalado esvaziamento das aulas de Educação Física não estaria justamente no pressuposto tomado pelos professores que todos gostam e "precisam" competir? Não é possível responder aqui tantas questões, tampouco é o meu objetivo. Mas há muito tenho procurado estabelecer conexões entre o que se faz hoje nas aulas de Educação Física, o interesse particular e de grupo dos alunos e o papel formativo da Educação Física. E antes que o leitor me recrimine por desconsiderar nessas reflexões as influências externas à escola, como a indústria cultural, por exemplo, vale lembrar que essas influências estão sempre no meu horizonte, uma vez que não concebo a escola como um lugar absolutamente autônomo em relação ao contexto social. Também no que respeita aos interesses dos alunos, vale lembrar que eles podem estar calcados em falsas necessidades, como realmente estão. Mas aqui salta aos olhos um dos papéis preponderantes da instituição escolar: o necessário desvelamento do caráter ideológico que a cultura assume na sociedade administrada.

Se o elemento competitivo se afirma por aquilo que tem justamente de dominador, como já indiquei, ele se afirma também justamente pela reificação das relações entre os indivíduos. Ainda que exista quem defenda as práticas de competição como uma forma de catárse, acredito que essa postura representa uma estratégia de amoldamento, de adaptação: uma vez que o indivíduo libera energias através de práticas competitivas, não estaríamos pressupondo um indivíduo justamente adaptado, uma vez que sua possível potência contestatória 
estaria devidamente controlada? E qual seria o eixo ético de uma prática voltada apenas para o controle da consciência e mesmo para o controle pulsional? Por isso o pressuposto da canalização da energia tem muito de ideológico, pois mantém o sujeito em um espaço de heteronomia, e não de autonomia.

Mas seria possível uma concepção de Educação Física que não estivesse pautada no princípio competitivo? A resposta para essa questão depende de como concebemos o processo de formação. E é Vago a quem acompanho nessa reflexão.

Finalmente, é preciso enfrentar essa questão: é possível à Educação Física atingir as dimensões singular e social do ser humano? Depende!

Depende da Educação Física escolar rever seus vínculos históricos de subserviência ao mundo do trabalho na perspectiva capitalista;

Depende de a Educação Física se permitir abdicar de uma concepção unilateral de ser humano que privilegia o biológico, o padronizável, o mensurável, e se abrir para uma concepção omnilateral de ser humano, na qual suas múltiplas formas de expressão corporal sejam respeitadas, pesquisadas e enriquecidas;

Depende de a Educação Física se deixar contagiar pela infinita capacidade que o ser humano possui de criar, inventar, recriar, reinventar, viver, sentir, experimentar, numa palavra, provar o corpo humano e a vida de movimento que dele emana;

Depende de a Educação Física se pautar pelo fato histórico de que o ser humano é corporeidade que também pode ser provada ludicamente, e que essa experiência corporal lúdica dos seres humanos tem repercussões sociais, pois numa sociedade que os empurra para a tristeza, para o individualismo, para o isolamento, o lúdico se apresenta como contradição a essa sociedade, propondo o riso, a alegria, a aproximação, o coletivo, desde que verdadeiro e, ao mesmo tempo, crítico. (VAGO, 1995, p. 23)

Nesses termos, concebida a formação como um processo de adaptação do indivíduo ao meio, de conformação, então a competição é um elemento essencial, uma vez que a sociedade planejada está radicada na eliminação da potência criadora dos indivíduos. Por outro lado, se concebemos a formação como um processo de emancipação, de autonomia, de auto-reflexão, de alteridade e de resistência, as práticas competitivas pouco ou nada teriam a contribuir. Por isso em outra oportunidade já duvidava das possibilidades de encontro com o outro preconizadas por Adorno em Educação após Auschwitz (1995): o esporte ou qualquer outra prática onde haja contendores só pode se basear no primado do melhor, do mais forte, do vencedor, do melhor preparado. Nessas condições o reconhecimento do outro será sempre uma condição de reconhecimento da autoridade: o perdedor reconhecendo a superioridade da adversário; o vencedor reconhecendo o esforço e a resignação daquele. Não estaríamos falando de dominação e de sacrifício? 
O fato insistentemente negado é que a cultura nos oferece uma conjunto de possibilidades corporais formativas que apontam, essas sim, para práticas ancoradas na participação, na cooperação, no reconhecimento dos limites e possibilidades particulares, enfim, um campo de possibilidades de efetivo encontro entre os indivíduos. Quando os alunos se organizam em torno de uma dança, de um jogo, de uma encenação que tem um fim em si mesmo, ou seja, que represente um momento de fruição desses alunos, que aspecto agonístico estaria em jogo? Nenhum! A atividade se afirma pelo seu valor em si e não pelos resultados que da sua consecução possam advir. Muitos obstarão que eu estaria sendo idealista. A epígrafe desse texto já indica o meu intento!

Adorno e Horkheimer nos ensinam que o processo de esclarecimento nas suas duas dimensões - se desenvolveu como um sistema:

\begin{abstract}
O pensamento no sentido do esclarecimento, é a produção de uma ordem científica unitária e a derivação do conhecimento factual a partir de princípios, não importa se estes são interpretados como axiomas arbitrariamente escolhidos, idéias inatas ou abstrações supremas. As leis lógicas estabelecem as relações mais gerais no interior da ordem, elas as definem. A unidade reside na concordância. O princípio da contradição é o sistema in nuce. O conhecimento consiste na subsunção a princípios. Ele coincide com o juízo que se inscreve no sistema. Um pensamento que não se oriente para o sistema é sem direção ou autoritário. A razão fornece apenas a idéia de unidade sistemática, os elementos formais de uma sólida conexão conceitual. Todo objetivo a que se refiram os homens como um discernimento da razão é, no sentido rigoroso do esclarecimento, desvario, mentira, "racionalização", mesmo que os filósofos dediquem seus melhores esforços para evitar essa consequiência e desviar a atenção para o sentimento filantrópico. (ADORNO; HORKHEIMER, 1985, p. 81-82)
\end{abstract}

Esse sistema não estaria na gênese do ideal olímpico de congraçamento entre os povos? E não estaria implícito na ideologia do fair-play? Ora, a realidade tem nos dado inúmeras mostras através da história, dos usos que podem ser feitos das atividades orientadas pelo princípio da competição. Desde o enfrentamento político-ideológico de nações e blocos de nações até a idiotização da infância em programas televisivos absolutamente reificadores. Portanto, deixemos a pusilanimidade de lado! Poderemos continuar insistindo em práticas escolares que depõem frontalmente contra a possibilidade emancipatória dos indivíduos? Ou, no mínimo, contra sua potencialidade crítica? Mas como podemos desenvolver essas duas dimensões sonegando aos nossos alunos o conhecimento há muito produzido sobre as possibilidades expressivas e comunicativas do corpo? A plasticidade, a sensibilidade, a alteridade há muito estão fora das aulas de Educação Física. Por que uma prática como a GRD, por exemplo, precisa logo tornar-se uma prática de exclusão, de competição? 
Abstraída a sua dimensão agonística expressa num rigoroso código de pontuação - que tem como função classificar, ordenar, hierarquizar os sujeitos não seria essa prática portadora de elementos suficientes para desenvolver a sensibilidade dos participantes, no plano mesmo da suas possibilidades individuais (não exclusivas) de expressão, no desenvolvimento do seu senso estético, e da sua possibilidade de construir junto com os demais uma determinada manifestação corporal? Ou seja, exercendo uma participação autônoma na direção do encontro com o outro. Essa maneira de conceber os conhecimentos da Educação Física não seria, efetivamente, uma possibilidade de reverter o estranhamento que o outro nos provoca, que acaba por fazer que nos voltemos contra ele? Essas práticas não competitivas não representariam formas de resistência a um "sistema" que se afirma pela aniquilação do sujeito autônomo e pelo enaltecimento do mais forte?

O exemplo tomado da GRD parece-me emblemático por possibilitar um paralelo entre as duas formas de conceber os saberes da Educação Física no interior da escola. Infelizmente hoje ela tem sido tratada meramente na sua dimensão esportiva (quando é tratada), negando ao conjunto dos indivíduos o acesso às suas práticas, que pressupõem um trabalho expressivo-estético baseado na cooperação entre diferentes sujeitos autônomos. Mas outros exemplos poderiam ser tomados: a dança, a dramatização, a ginástica são todas elas práticas corporais que permitem aos indivíduos manifestar seus interesses e possibilidades em relação aos outros indivíduos, sem que isso represente ser melhor ou pior, menos ou mais, o primeiro ou o último. Elas se afirmam pelo que são; seu valor está justamente no fim a que servem: o prazer de fazer algo e de formar-se sem as amarras do utilitarismo. Isso até que chegue um professor e transforme tudo em torneios, campeonatos, gincanas, treinamentos...

Pensar sobre uma outra forma de desenvolver a Educação Física é um exercício necessário, senão urgente. Mas não se trata aqui de desenvolver propostas: estas serão desenvolvidas à medida que cada professor reorientar as relações que estabeleceu com o conhecimento. Seguindo Adorno, "Onde falta a reflexão do próprio objeto, onde falta o discernimento intelectual da ciência, instala-se em seu lugar a frase ideológica [...]" (1995, p. 62). Mas a prática dos professores está também (mas não só) orientada por uma visão canhestra das possibilidades formativas da Educação Física e mesmo da sua inserção no plano da cultura.

Isto porque a formação cultural é justamente aquilo para o que não existem à disposição hábitos adequados; ela só pode ser adquirida mediante esforço espontâneo e interesse, não pode ser garantida simplesmente por meio da frequiência de cursos, e de qualquer modo estes seriam do tipo "cultura geral". 
Na verdade, ela nem ao menos corresponde ao esforço, mas sim à disposição aberta, à capacidade de se abrir a elementos do espírito, apropriando-se de modo produtivo na consciência, em vez de se ocupar com os mesmos unicamente para aprender, conforme prescreve um clichê insuportável. (ADORNO, 1995, p. 64)

Com essas considerações quero destacar a importância que confiro tanto à formação de professores, quanto - e principalmente - à sua atuação cotidiana. Enquanto os cânones da indústria cultural continuarem orientando muitas das práticas escolares, não poderemos sequer esboçar qualquer tipo de resistência, uma vez que estaremos encharcados de influências que obliteram a nossa consciência de conformados. A contraface dessa influência seria um trabalho desenvolvido com o que de mais significativo foi produzido em termos culturais pelo gênero humano no campo das práticas corporais. O resgate dos ideais estéticos, morais e intelectuais do humanismo iluminista, sonegados pelo próprio processo do esclarecimento, são a pedra de toque de uma formação que supere a instrumentalização da razão humana. Mas esse resgate deverá abstrair necessariamente o utilitarismo e o caráter elitista da cultura ambos expressão acabada da dominação - pontificado por Marcuse como o vir a ser da burguesia que se afirmava:

\begin{abstract}
Os grupos da burguesia em ascensão haviam fundamentado sua exigência por uma nova liberdade pessoal mediante a razão humana universal. Confrontavam a crença na eternidade divina de uma ordem restritiva com a sua crença no progresso, em um futuro melhor. Contudo razão e liberdade não extrapolavam o interesse daqueles grupos, que se opunha mais e mais ao interesse da maioria. Aos questionamentos acusadores a burguesia dava uma resposta decisiva: a cultura afirmativa. Em seus traços fundamentais ela é idealista. Às necessidades do indivíduo isolado ela responde com a característica humanitária universal; à miséria do corpo, com a beleza da alma; à servidão exterior, com a liberdade interior; ao egoísmo brutal, com o mundo virtuoso do dever. Se na época do ascenso combativo da nova sociedade todas essas idéias possuíam um caráter progressista não restrito à organização vigente da existência, entretanto com estabilização da dominação burguesa elas se colocam crescentemente a serviço do controle das massas insatisfeitas e da mera auto-exaltação legitimadora: elas ocultam a atrofia corporal e psíquica do indivíduo. (1997, p. 98-99)
\end{abstract}

No conceito de cultura afirmativa de Marcuse ou de indústria cultural de Adorno e Horkheimer podemos inferir o tipo de influência sofrida pelas práticas escolares. A indústria do corpo - saúde, beleza, lazer, produtos esportivos, esportes radicais, hiper-exposição corporal, erotização precoce - tem determinado em larga medida práticas escolares de Educação Física. Assim, a riqueza da dança se converte num cover de grupos de qualidade no mínimo duvidosa; 
os jogos passam a ter como referentes grandes ídolos do esporte; as artes marciais aparecem como mecanismo de defesa e não como possibilidade de expansão da consciência; sem contar a profusão de temas country que têm animado inúmeros eventos escolares. Portanto, as práticas escolares têm concorrido para a perpetuação da heteronomia, do estranhamento e reificação das pessoas e das coisas. Mas, para além de eventos isolados, o cotidiano das aulas de Educação Física também está submetido à miséria da cultura afirmativa: a cisão entre corpo e alma indica claramente o lugar de cada sujeito em relação às suas possibilidades de acesso à cultura:

\begin{abstract}
A alma glorifica a resignação. Superando todas as diferenças naturais e sociais, o que importa afinal é o homem, particular, insubstituível; entre os homens deve existir verdade, bondade e justiça; todas as fragilidades humanas devem ser expiadas pelo puro humanitarismo: um ideal assim, numa sociedade determinada pela lei do valor da economia, só pode ser representado pela alma e como acontecimento anímico. Somente da alma pura pode partir a salvação. Todo o resto é desumano, desprovido de crédito. A alma sozinha evidentemente não tem valor de troca. $\mathrm{O}$ valor da alma não é incorporado nela de modo a se consolidar em seu corpo como objeto que pode se converter em mercadoria. Há uma bela alma num corpo feio, uma alma saudável num corpo doente, uma alma nobre num corpo mesquinho - e vice-versa. Existe um cerne de verdade na afirmação segundo a qual o que acontece com o corpo não pode afetar a alma. Mas esta verdade assumiu uma forma terrível na ordem vigente. A liberdade da alma foi utilizada para desculpar miséria, martírio e servidão. Ela serviu para submeter ideologicamente a existência à economia do capitalismo. Porém, apreendida corretamente, a liberdade da alma não aponta para a participação do homem num além eterno, onde por fim tudo se resolve quando o indivíduo já não usufrui de nada. Ao contrário, ela pressupõe aquela verdade superior segundo a qual nesse mundo é possível uma forma de existência social em que a economia não decide acerca de toda a vida dos indivíduos. O homem não vive apenas de pão: uma verdade como esta não se esgota pela falsa interpretação de que o alimento espiritual é um substituto suficiente para a falta de pão. (MARCUSE, 1997, p. 109)
\end{abstract}

O que tem se perpetuado nas práticas escolares de Educação Física é a negação das possibilidades de formação dos indivíduos em toda a sua dimensão humana. A forma de tratar o conhecimento no interior das aulas de Educação Física - e da escola de maneira geral - tem se mostrado como um forte elemento mantenedor da ordem vigente. A sua face desumana é reforçada pela negação aos indivíduos do acesso ao que de mais rico foi produzido pela cultura. A forma pastiche assumida pela cultura de massa reduz as possibilidades críticas dos indivíduos na mesma proporção que os submete ao encantamento do mundo descartável, efêmero, banal. Nesse contexto as práticas culturais - 
dentre as quais a Educação Física - só podem emergir como condição manifesta da pseudoformação:

\begin{abstract}
A formação cultural agora se converte em uma semiformação socializada, na onipresença do espírito alienado, que, segundo sua gênese e seu sentido, não antecede à formação cultural, mas a sucede. Deste modo, tudo fica aprisionado nas malhas da socialização. Nada fica intocado na natureza, mas sua rusticidade - a velha ficção - preserva a vida e reproduz-se de maneira ampliada. Símbolo de uma consciência que renunciou à autodeterminação, prende-se de maneira obstinada, a elementos culturais aprovados. Sob seu malefício gravitam como algo decomposto que se orienta à barbárie. Isso tudo não encontra explicação a partir do que tem acontecido ultimamente, nem, certamente, como expressão tópica da sociedade de massas, que, aliás, nada consegue explicar mesmo, apenas assinala um ponto cego ao qual deveria se aplicar o trabalho do conhecimento. Apesar de toda ilustração e de toda informação que se difunde (e até mesmo com sua ajuda) a semiformação passou a ser a forma dominante da consciência atual, o que exige uma teoria que seja abrangente. (ADORNO, 1996, p. 389)
\end{abstract}

Por que, então, insistimos numa forma de "educação" baseada na obliteração da consciência, na negação das possibilidades emancipatórias dos indivíduos, na reificação das relações entre eles, manifestas em práticas competitivas? Não tenho dúvidas quanto ao fato, já afirmado no início deste trabalho, de sequer sabermos bem o porquê de ensinarmos Educação Física. Assim, aprovamos o que já está previamente aprovado, nos eximimos do nosso papel crítico e questionador e nos submetemos à vontade tirânica do mercado da banalização cultural. A competição como tópica das aulas de Educação Física não assume só um caráter ideológico manifesto; ela representa também o exemplo mais acabado de como a mediocridade foi internalizada como valor. Não é isso que aflora quando afirmamos defensivamente que os nossos alunos adoram o esporte, adoram competir? Tomamos como dado natural um construto histórico. E nos submetemos passivamente à razão reificada que estabelece que devemos ir mais longe, mais rápido, com mais empenho. A essa Educação Física calcada numa formação instrumental redutiva das possibilidades de auto-reflexão e resistência dos indivíduos, a formação cultural contraporia um lugar de exercício de autodeterminação a partir de toda a riqueza formativa da qual a cultura é possibilidade:

[...] é ainda a formação cultural tradicional, mesmo que questionável, o único conceito que serve de antítese à semiformação socializada, o que expressa a gravidade de uma situação que não conta com outro critério, pois descuidou-se de suas possibilidades. Não se quer a volta do passado nem se abranda a crítica a ele. Nada sucede hoje ao espírito objetivo que não estivesse já inscrito nele desde os tempos mais liberais, ou que, pelo menos, não exija o cumprimento de 
velhas promessas. O que agora se denuncia no domínio da formação cultural não se pode ler em nenhum outro lugar a não ser em sua antiga figura, que como sempre, também é ideológica. Potencialmente foram cortados os petrificados recursos com que o espírito podia escapar da formação tradicional e sobrepassá-la. A medida da nova perversidade é a anterior. Revela-se num momento, pois está condenada, diante da forma última do constrangimento, como uma cor que tenta manter os tons que se desvanecem. (ADORNO, 1996, p. 395-396)

Assim, ainda que seja uma criação eminentemente burguesa, o esporte moderno vinculou-se a essa dimensão da cultura denunciada como afirmativa por Marcuse. O princípio competitivo inerente à sua prática se desenvolveu na perspectiva da manutenção da ordem e de conformação dos indivíduos. E para além das práticas esportivas essa perspectiva se espraiou para o conjunto das práticas corporais no meio escolar. A moral que a informa é a moral apontada por Adorno e Horkheimer no Excurso II da Dialética do esclarecimento (1985). Para Juliette todos os órgãos devem servir à dominação, à crueldade. Não sendo neutra a razão se apresenta como negação do prazer e a crueldade se liga ao gozo. A falsa liberdade de pulsões, que a cultura pretensamente nos oferece, representa na verdade a outra face da dominação. Não por outro motivo, a moral da sociedade disciplinada, administrada nos remete ao gozo. Essa dinâmica aponta para a constituição do indivíduo narcisista de hoje, que é frio e calculista, centrado apenas na autoconservação. Não é o caso do corpo utilitário da indústria cultural? O prazer não nos tem sido apresentado como o fim último da existência? Mas se o princípio é válido, é preciso indagar: de que prazer nos fala a indústria cultural e que moral a orienta?

\footnotetext{
É só com o progresso da civilização e do esclarecimento que o eu fortalecido e a dominação consolidada transformam o festival em simples farsa. Os dominadores apresentam o gozo como algo racional, como tributo à natureza não inteiramente domada; ao mesmo tempo procuram torná-lo inócuo para seu uso e conservá-lo na cultura superior; e, finalmente, na impossibilidade de eliminá-lo totalmente, tentam dosá-lo para os dominados. O gozo torna-se objeto de manipulação até desaparecer inteiramente nos divertimentos organizados. (ADORNO; HORKHEIMER, 1985, p. 101)
}

Qual seria mesmo o objetivo das práticas competitivas no interior da escola? Atender às necessidades de competir, de movimentar-se, de enfrentarse dos nossos alunos? Mas se assim for, não deveríamos pressupor que a sua formação deveria levar em conta o desenvolvimento da autonomia que pressupõe um contexto social de aproximação e reconhecimento do outro em sua singularidade, e não a sua aniquilação como potencial criativo? 
Todo gozo, porém, deixa transparecer uma idolatria: ele é o abandono de si mesmo a uma outra coisa. A natureza não conhece propriamente o gozo: ela não o prolonga além do que é preciso para a satisfação da necessidade. Todo prazer é social, quer nas emoções não sublimadas quer nas sublimadas, e tem origem na alienação. Mesmo quando o gozo ignora a proibição que transgride, ele tem sempre por origem a civilização, a ordem fixa, a partir da qual aspira retornar à natureza, da qual aquela o protege. Os homens só sentem a magia do gozo quando o sonho, liberando-os da compulsão do trabalho, da ligação do indivíduo a uma determinada função social e finalmente a um eu, leva-os de volta a um passado pré-histórico sem dominação e sem disciplina. É a nostalgia dos indivíduos presos na civilização, o "desespero objetivo" daqueles que tiveram que se tornar em elementos da ordem social, que alimenta o amor pelos deuses e demônios; era para estes, enquanto natureza transfigurada, que eles se voltavam na adoração. O pensamento tem origem no processo de liberação dessa natureza terrível, que acabou por ser inteiramente dominada. O gozo é por assim dizer sua vingança. Nele os homens se livram do pensamento, escapam à civilização. (ADORNO; HORKHEIMER, p. 100-101)

As práticas competitivas, reduzindo toda a possibilidade formativa das práticas corporais desenvolvidas ao longo da história, tem se mostrado a maneira mais fácil de sequer pensarmos sobre o que existe de embusteiro no argumento de que todos gostam de competir. Talvez assim seja se considerarmos que o prazer da competição tem algo de sádico quando reiteramos nossa condição de vencedores e submetemos nossos adversários. A afirmação do narcisismo propiciada por essa forma de conceber a Educação Física escolar tem, consequentemente, infirmado o corpo livre, uma vez que o apreende como dominação da natureza que nega aquele. Tem negado, portanto, a possibilidade de sentirmos com todos os sentidos. Dessa maneira os agentes - professores - das práticas escolares, ao reivindicar o prazer do aluno como justificativa para a competição, atuam no campo de uma mentira manifesta. Atuam no campo da dissimulação.

Mas, no outro extremo é preciso reconhecer que fundada na experiência, a resistência a esse estado de coisas emerge do próprio cotidiano de alunos e professores. $\mathrm{O}$ esvaziamento das aulas não seria uma das práticas possíveis de resistência? Apesar do esforço despendido pela educação na reificação e conformação dos indivíduos, todos sabemos que emergem do processo educacional sujeitos capazes de alguma autonomia e resistência. Esses sujeitos acabam por desenvolver sua sensibilidade como potência capaz de inseri-lo criticamente na realidade. Essa sensibilidade indica a possibilidade de o indivíduo diferenciar-se do outro reconhecendo-o como diferente, a ser respeitado. Ela não implica, basicamente, em práticas de dominação e submissão do outro diferente. Daí o princípio da competição perpetuar de forma dissimulada a pseudoformação. E essa se manifesta como um bloqueio da experiência que 
emperra o desenvolvimento autônomo do indivíduo e sua relação com o outro. Estamos diante de uma opção muito clara: ou privilegiamos a força e a violência, substrato de práticas corporais competitivas, ou privilegiamos a delicadeza e a sensibilidade. Definitivamente o esclarecimento deve contrapor-se ao sacrifício implícito em toda prática competitiva. Afinal, a cultura é meio para aproximação dos indivíduos. A instrumentalização, característica básica da Educação Física desenvolvida em nossas escolas ainda hoje, não forma, mas deforma. E o elemento emancipatório do conhecimento está justamente na sua possibilidade reflexiva. A educação deve despertar o indivíduo, fazer sentido para ele. Uma educação baseada na adaptação está radicada na miséria da experiência. Negar o conhecimento é negar a reflexão e a autonomia. A potência criativa e imaginativa dos indivíduos não pode se desenvolver no vazio; ela requer conhecimentos. Somente diante dessa relação é possível assumir plenamente as considerações de Vago expressas acima, acerca da criatividade humana. A pobreza cultural das aulas de Educação Física é patente nesse sentido: elas só podem servir à reificação, à dominação, à obliteração da consciência quando reduz a experiência dos alunos a um arremedo de formação que atende por diversos codinomes: educação do movimento, educação para o movimento, educação pelo movimento, educação através do movimento... Nossos alunos hoje são reféns de uma tradição longínqua manifesta no "corpo coisa" destacado por Marcuse e Adorno e Horkheimer no seu Interesse pelo corpo. Se as manifestações corporais no interior da instituição escolar devem permanecer circunscritas a um restrito número de práticas de competição, que obedecem a códigos herméticos e a uma lógica medíocre do subsunção à ordem instaurada, os indivíduos sujeitos dessas manifestações jamais poderão exercitar sua liberdade. E se a linguagem corporal não pode ser livre, necessariamente o pensamento está impedido de desenvolver-se livremente. Ou seja, nossas práticas escolares tem realimentado o círculo da dominação ao submeter os alunos a elementos ínfimos daquilo que a humanidade produziu como práticas corporais. E mais que isso, ao submetê-lo a um conhecimento norteado pela comezinha lógica dos vencedores diante dos vencidos.

O prazer na humilhação dos outros e na própria humilhação sob uma vontade mais forte, o prazer nos numerosos substitutos da sexualidade, no sacrifício sem sentido, no heroísmo da guerra é, por conseguinte, uma falso prazer, porque os impulsos e necessidades que com ele se satisfazem tornam os homens menos livres, mais cegos e mesquinhos do que precisariam ser. São impulsos e necessidades dos indivíduos formados numa sociedade antagônica. Na medida em que não deveriam desaparecer inteiramente com uma nova forma de organização social, poder-se-iam pensar maneiras de satisfazê-los em que realmente 
as extremas possibilidades dos homens se desenvolvessem de maneira feliz. Essa libertação das possibilidades tem a ver com a práxis social; aquilo que os homens podem apreender com os órgãos desenvolvidos dos sentidos e da alma e com a riqueza criada pelo seu trabalho para alcançar o máximo de felicidade depende dessa práxis. Assim concebida, a felicidade não pode mais ser algo meramente subjetivo: ela entra na esfera do pensamento e do agir comunitário dos homens. (MARCUSE, 1997, p. 188-189)

Tanto quanto Adorno e Horkheimer, Marcuse também adverte para a necessidade da felicidade e liberdade humanas só poderem se efetivar no plano da libertação da própria sociedade. Assim, ainda que minha análise tenha centrado foco nas práticas escolares de Educação Física especificamente, é importante reiterar que não pretendi uma análise particularista. Com isso quero dizer que compreendo a Educação Física no contexto mais amplo de uma sociedade desumana e totalitária. Portanto, a Educação Física é incapaz de mudar a relação entre os indivíduos por si só. Porém, como prática inscrita na cultura, ela está sujeita ao mesmo duplo movimento do esclarecimento: pode servir como prática de resistência, denúncia, crítica e superação do indivíduo tornado mônada como pode submeter-se às orientações que reafirmam dioturnamente a reificação do indivíduo, a banalização da cultura e a eficácia da dominação. Não se trata, pois, de jogar fora a água da bacia com a criança junto. Para Marcuse é preciso de todas as formas resgatar os "pressupostos da liberdade":

[...] o desenvolvimento das necessidades materiais tem de ir junto com o desenvolvimento das necessidades da alma e do espírito. A utilização da técnica, da ciência e da arte se modifica ao modificarem-se sua utilização e seu conteúdo: quando elas não estiverem mais sob a coerção de um sistema de produção vinculado à infelicidade da maioria e às exigências da racionalização, da interiorização e da sublimação, o espírito só pode significar um aumento da felicidade. O hedonismo é superado e conservado (Aufhebung) na teoria e na práxis críticas; se a liberdade dominar também no âmbito da vida anímica e espiritual, quer dizer, na cultura, se esta não estiver mais sob a coerção da interiorização, torna-se sem sentido limitar a felicidade ao prazer sensível.

A realidade da felicidade é a liberdade, como autodeterminação da humanidade emancipada na sua luta comum com a natureza. (MARCUSE, 1997, p. 198-199)

Esse é o fundamento primeiro de uma formação para a resistência: indagar que papel têm cumprido nossas práticas escolares no processo de formação dos indivíduos. E em que medida a dimensão agonística e o empobrecimento do saber por nós abordado pode contribuir efetivamente para uma formação que busque a autonomia e a alteridade como formas de resistência ao que está instituído. O fato de a formação burguesa estar cindida 
em uma formação diferenciada para dominadores e dominados é indicativa daquilo que os primeiros pretendem: a perpetuação da dominação. As relações estabelecidas nas práticas competitivas entre vencedores e vencidos conseguiu alguma vez produzir efeitos formativos relevantes do ponto de vista da formação humana? Afinal, quem escreve a história?

\section{REFERÊNCIAS}

ADORNO, Theodor. A filosofia e os professores. In: Educação e emancipação. São Paulo: Paz e Terra, 1995.

Teoria da semicultura. Educação e Sociedade, n. 56, p. 388-411, dez. 1996.

ADORNO, Theodor; HORKHEIMER, Max. Ulisses ou mito e esclarecimento. In: Dialética do esclarecimento. Rio de Janeiro: Zahar, 1985.

; . Juliette ou esclarecimento e moral. In: ; _ـ Dialética do esclarecimento. Rio de Janeiro: Zahar, 1985. ; __ Interesse pelo corpo. In: ; __. Dialética do esclarecimento. Rio de Janeiro: Zahar, 1985.

MARCUSE, Herbert. Sobre o caráter afirmativo da cultura. In: Cultura e sociedade. São Paulo: Paz e Terra, 1997. 1997. . Para a crítica do hedonismo. In: Cultura e sociedade. São Paulo: Paz e Terra,

VAGO, Tarcísio Mauro. Educação Física escolar: temos o que ensinar? Revista Paulista de Educação Física, São Paulo, supl. n. 1, p. 20-24, 1995. 